Discussion Paper No. 10-094

Do Environmental Benefits Matter?

A Choice Experiment

Among House Owners in Germany

Martin Achtnicht

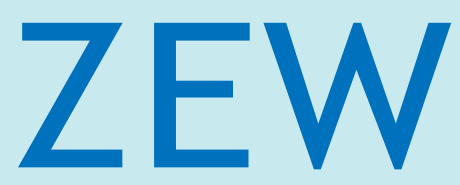

Zentrum für Europäische Wirtschaftsforschung $\mathrm{GmbH}$

Centre for European

Economic Research 
Discussion Paper No. 10-094

\title{
Do Environmental Benefits Matter? A Choice Experiment Among House Owners in Germany
}

\author{
Martin Achtnicht
}

Download this ZEW Discussion Paper from our ftp server:

ftp://ftp.zew.de/pub/zew-docs/dp/dp10094.pdf

Die Discussion Papers dienen einer möglichst schnellen Verbreitung von neueren Forschungsarbeiten des ZEW. Die Beiträge liegen in alleiniger Verantwortung der Autoren und stellen nicht notwendigerweise die Meinung des ZEW dar.

Discussion Papers are intended to make results of ZEW research promptly available to other economists in order to encourage discussion and suggestions for revisions. The authors are solely responsible for the contents which do not necessarily represent the opinion of the ZEW. 


\section{Non-technical Summary}

The residential building sector is a major emitter of the greenhouse gas carbon dioxide $\left(\mathrm{CO}_{2}\right)$ due to the high energy demand for electricity and heating, particularly in industrialised countries. In Germany, for example, approximately 30 percent of the total energy produced is consumed in residential buildings, with space (74 percent) and water heating (11 percent) dominating.

Given the European Union Greenhouse Gas Emission Trading System (EU ETS), decentralised heat generation is of particular relevance for future climate policy. Unlike electricity and district heating, emissions arising from decentralised heat generation are not covered by the EU ETS. Therefore, measures to save heat energy in residential buildings are likely to result in effective $\mathrm{CO}_{2}$ abatement and not just in a shift of emissions. In view of an annual refurbishment rate of approximately one to two percent, there is still considerable energy-saving potential. However, German regulations currently in force mostly prescribe standards, and thus ignore individual preferences.

In order to know house owners' preferences on heating and insulation technologies and to learn more about their decisions we conducted a choice experiment concerning energy retrofits for existing houses in Germany. The sample consists solely of owner-occupiers of single-family detached houses, semidetached houses and row houses. In the experiment, participating house owners could either choose a modern heating system or an improved thermal insulation for their house. Unlike previous studies, we explicitly included both cost and environmental benefits of energy-saving measures.

In particular, we find environmental benefits to have a significant impact on choices of heating systems. However, they played no role in terms of insulation choices. We further obtain substantial WTP measures for $\mathrm{CO}_{2}$ savings. Therefore, we conclude that house owners are aware of their responsibility and willing to contribute to climate protection. However, there are a lot of uncertainties which hinder investments in energy-efficient technologies in the real world, but which were abstracted in the experiment. Our results suggest that future policies should address the market failure of information asymmetry and reduce related uncertainties as far as possible, rather than implement further and stricter standards. 


\section{Das Wichtigste in Kürze}

Aufgrund der starken Energienachfrage von privaten Haushalten, insbesondere in Industrieländern, ist der Wohngebäudesektor einer der bedeutendsten Emittenten des Treibhausgases Kohlenstoffdioxid $\left(\mathrm{CO}_{2}\right)$. Beispielsweise entfallen in Deutschland 30 Prozent des gesamten Endenergieverbrauchs allein auf private Haushalte. Der Großteil der konsumierten Energie wird hierbei zur Beheizung des Wohnraums (74 Prozent) und zur Warmwasserbereitung (11 Prozent) genutzt.

Die dezentrale Erzeugung von Wärme in Wohngebäuden ist angesichts des bestehenden Emissionshandelssystem der EU (EU ETS) von besonderer Bedeutung für zukünftige Klimapolitik. Denn $\mathrm{CO}_{2}$-Emissionen, die bei der dezentralen Wärmeerzeugung entstehen, sind, anders als die im Kraftwerk bei der Produktion von Strom und Fernwärme anfallenden Emissionen, nicht durch das EU ETS erfasst. Maßnahmen zur Einsparung von Wärmeenergie in Wohngebäuden haben deshalb das Potential, tatsächlich klimarelevante $\mathrm{CO}_{2}$-Emissionen zu vermeiden und diese nicht nur in andere Sektoren zu verlagern. In Anbetracht einer jährlichen Sanierungsrate von ca. ein bis zwei Prozent gibt es durchaus ein beträchtliches Einsparpotential in diesem Sektor. Allerdings werden Sanierungswilligen in Deutschland derzeit bestimmte Standards vorgeschrieben, und somit deren individuelle Präferenzen ignoriert.

Um mehr über die Präferenzen von Hauseigentümern bezüglich Heiz- und Dämmtechnologien herauszufinden, haben wir deutschlandweit ein sog. choice experiment zum Thema energetische Modernisierungsmaßnahmen durchgeführt. Die erhobene Stichprobe besteht ausschließlich aus selbstnutzenden Eigentümern von Einfamilien-, Zweifamilien- und Reihenhäusern. Im Rahmen des Experiments wurden die Teilnehmer jeweils vor die hypothetische Wahl zwischen einem modernen Heizsystem und einer verbesserten Wärmedämmung für ihr Haus gestellt. Im Gegensatz zu früheren Studien haben wir neben den Kostenvorteilen auch die mit einer energetischen Sanierung einhergehenden Umweltvorteile explizit einbezogen.

Es zeigt sich insbesondere, dass Umweltvorteile die Wahl eines Heizsystems positiv beeinflussen, hinsichtlich Dämmsystemen jedoch keine Rolle spielen. Darüber hinaus leiten wir aus den beobachteten Wahlentscheidungen beträchtliche Zahlungsbereitschaften für vermiedene $\mathrm{CO}_{2}$-Emissionen ab. Wir kommen daher zu dem Schluss, dass Deutschlands Hauseigentümer grundsätzlich dazu bereit sind, 
ihren Teil zum Klimaschutz beizutragen. Allerdings bestehen in der Realität eine Reihe von Unsicherheiten und Intransparenzen, die Investitionen in energieeffiziente Technologien verhindern. Diese wurden im Experiment ausgeblendet. Unsere Ergebnisse legen daher nahe, dass die Politik in Zukunft verstärkt versuchen sollte, existierende Informationsasymmetrien und damit verbundene Unsicherheiten abzubauen, statt weitere und strengere Standards einzuführen. 


\title{
Do Environmental Benefits Matter? A Choice Experiment Among House Owners in Germany
}

\author{
Martin Achtnicht*
}

November 2010

\begin{abstract}
Residential buildings strongly contribute to global $\mathrm{CO}_{2}$ emissions due to the high energy demand for electricity and heating, particularly in industrialised countries. Within the EU, decentralised heat generation is of particular relevance for future climate policy, as its emissions are not covered by the EU ETS. We conducted a choice experiment concerning energy retrofits for existing houses in Germany. In the experiment, the approximately 400 sampled house owners could either choose a modern heating system or an improved thermal insulation for their home. We used standard and mixed logit specifications to analyse the choice data. We found environmental benefits to have a significant impact on choices of heating systems. However, they played no role in terms of insulation choices. Based on the estimated mixed logit model, we further obtained WTP measures for $\mathrm{CO}_{2}$ savings.

JEL classification: C25, D12, Q40, Q51.
\end{abstract}

Keywords: Choice experiment; $\mathrm{CO}_{2}$ emissions; Energy efficiency; Energy saving; Mixed logit; Residential buildings; Willingness to pay.

\footnotetext{
${ }^{*}$ Centre for European Economic Research (ZEW), L7,1, D-68161 Mannheim, Germany; Email: achtnicht@zew.de
} 


\section{Introduction}

In the course of efforts to address climate change and its negative impacts, the building sector has drawn the attention of policymakers. This sector is a major emitter of the greenhouse gas carbon dioxide $\left(\mathrm{CO}_{2}\right)$ due to the high energy demand for electricity and heating, mainly in OECD and non-OECD European countries (IEA, 2009). In Germany, for example, approximately 30 percent of the total energy produced is consumed in residential buildings. Together, space heating (74 percent) and water heating (11 percent) in residential buildings account for approximately one fourth of the end energy consumption (BMVBS, 2007).

Given the European Union Greenhouse Gas Emission Trading System (EU ETS), decentralised heat generation is of particular relevance for future climate policy. Unlike electricity and district heating, emissions arising from decentralised heat generation are not covered by the EU ETS. Therefore, measures to save heat energy in residential buildings are likely to result in effective $\mathrm{CO}_{2}$ abatement and not just in a shift of emissions. For example, buying a more energy-efficient heating system, shifting from a fossil-fueled to a non-fossil-fueled heating system, and improving the thermal insulation properties of exterior walls, roof, top ceiling, cellar ceiling or windows are reducing the $\mathrm{CO}_{2}$ emissions of a building, ceteris paribus.

In Germany, regulations addressing thermal insulation of buildings have existed for more than five decades; it all started with the DIN 4108 standard in its formulation of 1952. Currently, the Energy Savings Ordinance (ESO/EnEV) and the Renewable Energies Heat Act (REHA/EEWärmeG) are in force. ESO basically regulates the annual primary energy requirement and energy efficiency for heating, warm water and ventilation systems, as well as the transmission loss of the building envelope (EnEV, 2007, 2009). It applies to new buildings being constructed and existing buildings being reconstructed, retrofitted, or refurbished, that are regularly heated or cooled. According to ESO, for example, oil- and gasfired furnaces installed prior to October 1978 had to be removed by the end of 2008. Moreover, since January 2009, every owner who wants to sell or let his/her residential building has to make an energy pass available to prospective buyers and tenants. This energy pass contains information on the energy performance of the building and is intended to help interested parties to estimate the heating expen- 
diture, before the sale or lease contract is concluded. ESO hereby follows the EU's Directive on the energy performance of buildings (EU, 2002), which has recently been recasted (EU, 2010). Since 2009, new buildings being constructed have to partly cover their heat requirement by renewable energies, as prescribed by REHA (EEWärmeG, 2009). REHA thus aims to raise the share of renewables in Germany's heating energy consumption to 14 percent by 2020. If solely, for example, a solar thermal system is intended to be installed, at least 15 percent of the heating energy would have to be covered by this system. Heat pumps and wood-burning heating systems would have to provide at least half of the heating energy. Alternatively, house owners can comply with the required standards by using several renewable energy sources, local and district heating coming from cogeneration or waste heat recovery, as well as by overfulfilling the insulation standard defined by $\mathrm{ESO}$, or a combination of these measures. In addition to these mandatory requirements, there exist several public funding programmes to promote house owners' investments in energy efficiency and renewable energies.

Besides technical improvements, household behaviour is also relevant for residential energy use (e.g., Poortinga et al., 2003; Lindén et al., 2006). However, this paper focuses on technologies. Associated with high acquisition costs, the used heating equipment and the installed insulation system determine the energy use in buildings for years and even decades. Between 1989 and 2006 less than 30 percent of Germany's old buildings (i.e. residential buildings which were completed between 1900 and 1979) had been energy-efficiently refurbished (BMVBS, 2007). Given an annual refurbishment rate of approximately one to two percent, there is still considerable energy-saving potential. In order to design cost-effective policies that make an impact on residential energy use and related $\mathrm{CO}_{2}$ emissions, it is important to know house owners' preferences on heating and insulation technologies and to learn more about their decisions.

In this paper, we present the results of a choice experiment concerning energy retrofits for existing houses in Germany. The sample consists solely of owneroccupiers of single-family detached houses, semidetached houses and row houses. ${ }^{1}$ In the experiment, participating house owners could either choose a modern heating system or an improved thermal insulation for their house. Unlike previous

\footnotetext{
${ }^{1}$ It should be noted that the considered house types comprise 60 percent of Germany's total living space and almost 50 percent of Germany's residential units (IWU, 2007).
} 
studies, we explicitly included both cost and environmental benefits of energysaving measures. Based on the choice data, we estimate a standard and a mixed logit model. Moreover, we derive willingness to pay (WTP) estimates for $\mathrm{CO}_{2}$ savings.

The remaining paper is structured as follows: Section 2 gives a brief overview of existing literature on preferences for energy-saving measures in residential buildings and WTP for climate policy. The data and the methods used are described in detail in section 3 . In section 4 the results of our econometric analysis are presented and discussed. The final section summarises and concludes.

\section{Literature review}

Unlike this paper, previous studies on preferences for energy-saving measures in residential buildings did not focus explicitly on environmental benefits of such measures (e.g., Poortinga et al., 2003; Sadler, 2003; Banfi et al., 2008; Grösche and Vance, 2009; Kwak et al., 2010). However, their results suggest that not only cost benefits play a role in household decisions, but also other criteria. Sadler (2003) conducted two choice experiments among more than 600 owners of single-family detached houses across Canada. One experiment concerned home renovations, the other heating systems. Her results show that respondents preferred energy-efficient renovations compared to those without energy retrofits beyond included and observed cost and comfort attributes. Likewise, more efficient heating systems (e.g., high-efficiency gas furnaces and heat pumps) were preferred in the heating experiment. Interestingly, she further found differences in the implicit discount rate used for home renovations (21 percent) and heating systems (9 percent). Banfi et al. (2008) studied the WTP for energy-saving measures in Switzerland's residential buildings. They conducted a choice experiment among 163 apartment tenants and 142 house owners, who had recently moved. In the experiment, respondents could choose between their actual situation and an hypothetical alternative, which differed in the energy-efficiency levels of windows and façade, the presence of a ventilation system and the price (monthly rent for apartments, purchase price for houses). The obtained WTP estimates for the considered energy-saving measures were relatively high; they even exceeded related real-world capital costs, as shown by the authors. However, they include all kinds of benefits that potentially arise 
to respondents: cost-savings, increases in comfort, and environmental benefits. Kwak et al. (2010) recently conducted a similar study among 509 households from Korean metropolitan areas. They also found substantial WTP amounts for several heating energy-saving measures (i.e. increasing the number of window glasses and their variety, increasing the thickness of the façade, establishing a ventilation system). Grösche and Vance (2009) used revealed preference data from a German sample of 2530 single-family house owners and analyzed retrofit choices between 1995 and 2004. The surveyed retrofit measures were roof insulation, façade insulation, windows replacement, heating-equipment replacement, and their combinations. Based on engineering calculations of the respective energy savings, the authors estimated the WTP of households per kWh saved in the building's primary energy demand. By comparing the WTP estimates with the associated investment costs, they identified considerable incentives for free-ridership on public subsidisation. Using a conjoint analysis, Poortinga et al. (2003) examined to what extent the strategy (technical improvements vs. behavioural changes), the domain (home vs. transport) and the amount (small vs. large) of energy savings influence preferences for related measures. 455 Dutch households indicated the acceptability of 23 different energy-saving measures on a 5-point Likert-scale. The measures considered ranged from "switching off lights in unused rooms" and "shorter showers" to "energy-efficient heating system" and "house insulation". The results show that respondents particularly preferred technical improvements and home energysaving measures, while the amount of energy savings played seemingly no role for the acceptability.

In recent years, several studies have been conducted to obtain WTP measures for carbon abatements, carbon offsets, or climate change policy in general (e.g., Berrens et al., 2004; Hersch and Viscusi, 2006; Viscusi and Zeckhauser, 2006; Brouwer et al., 2008; Solomon and Johnson, 2009; MacKerron et al., 2009; Achtnicht, 2009). Using different stated preference methods and samples, the results of these studies are varying. Berrens et al. (2004) used higher energy and gasoline prices as payment mechanism in their contingent valuation (CV) study of U.S. households and found an annual mean WTP of approximately 192 dollars for GHG emissions reduction under the Kyoto Protocol. ${ }^{2}$ Viscusi and Zeckhauser

\footnotetext{
${ }^{2}$ The reported 192 dollars were obtained by using their most conservative estimator. The annual mean WTP increased to 816 dollars if only households with a positive WTP were con-
} 
(2006) surveyed Harvard students and found a median WTP of 0.50 dollars per gallon of gasoline and 3 percent of income to avoid global warming. The authors provided a rough calculation that converts the students' willingness to pay to curb climate change into an amount of 1,500 and 4,500 dollars per year, respectively. According to Hersch and Viscusi (2006) who used data from a 1999 Eurobarometer survey, Europeans aged 15-64 are on average willing to pay 2.3 euro-cents more per litre of gasoline to protect the environment. ${ }^{3}$ Also focusing on car fuel prices, Solomon and Johnson (2009) conducted a CV study in Michigan, Minnesota and Wisconsin to obtain the WTP for biomass or "cellulosic" ethanol. The observed additional WTP per gallon was translated by the authors into a mean total WTP of 556 dollars per capita per year. Unlike the mentioned studies, Brouwer et al. (2008) and MacKerron et al. (2009) considered carbon offsets in an aviation context. Brouwer et al. (2008) surveyed more than 400 air travel passengers in their CV study and found an average WTP of approximately 25 euros per tonne of $\mathrm{CO}_{2}$ equivalent. In addition to a CV question, MacKerron et al. (2009) used a choice experiment among UK adults aged 18-34 with a higher education qualification. The obtained mean WTP was 24 British pounds per tonne of $\mathrm{CO}_{2}$ from the CV question and 12.47 British pounds from the choice experiment (for the offset itself, plus another 11.14 for the offset certification). Achtnicht (2009) used data from a Germany-wide conducted choice experiment concerning car choices and reported an average median WTP of 68 euros per gram of $\mathrm{CO}_{2}$ per kilometre. Johnson and Nemet (2010) provide a more comprehensive survey of existing estimates of WTP for climate policy. They found the estimates to range from 22 to 437 dollars per household annually, with a median of 135 dollars (in 2008 U.S. dollars). However, the authors also emphasize the difficulties of comparing existing estimates, because the surveyed studies vary in their elicitation method, policy object under valuation, payment mechanism, explanatory variables, type of WTP measure, as well as size and nature of the sample. This paper contributes to the empirical literature by deriving German house owners' average WTP for saved $\mathrm{CO}_{2}$ emissions, using a choice experiment in an energy-saving context.

sidered.

${ }^{3}$ The WTP amount rose to 11.5 euro-cents, conditional on having a positive WTP. 


\section{Data and methods}

\subsection{Choice experiment}

In order to investigate preferences on energy-saving measures and its attributes we conducted a choice experiment among house owners in Germany. In particular, we were interested in the role that environmental benefits play compared to other benefits. Moreover, possible differences in valuing single attributes, depending on whether the given measure is a heating system or an insulation, were of particular interest to us. Though choice sets are hypothetical and choices are only stated, choice experiments seem to be the most appropriate method to study these issues. The researcher has full information about non-chosen alternatives, can vary attribute levels independently, is able to elicit WTP measures for non-market goods and, therefore, overcome possible drawbacks of revealed preference data (Louviere et al., 2000). Choice experiments have been employed in numerous and various empirical studies, some of which in an energy-saving context (e.g. Sadler, 2003; Banfi et al., 2008; Kwak et al., 2010).

In our choice experiment, interviewees were provided with two hypothetical measures of modernisation regarding their heating supply or heating usage respectively, from which they could choose. Specifically, they could either choose a modern heating system or an improved thermal insulation for their house. We thereby did not specify the concrete energy source (i.e. gas, oil, coal, wood, other biomass, solar-, air-, water- or geothermal-heat) or the part of the house for the insulation measure (façade/exterior wall, roof, top ceiling, cellar ceiling or windows). We rather asked interviewees to imagine the respective technology they would like to have for their home.

The alternatives to choose from were described by the following seven attributes: acquisition costs; annual energy-saving potential; payback period; $\mathrm{CO}_{2}$ savings; opinion of an independent energy adviser; public and/or private funding; and period of guarantee. Table 1 describes the attributes and the related levels in greater detail. It should be noted that the acquisition costs, the energy-saving potential and the payback period (i.e. the number of years after which the energysaving measure will pay off) could not be added up to another in our experiment. While the energy-saving potential was calculated with current energy prices only, 
the payback period should also include a supposed energy price development. Interviewees were informed about this context by the interviewer at the beginning of the experiment.

It should further be noted that the attribute levels of energy-saving potential had been customised to avoid unrealistic values. Interviewees were asked beforehand to state their annual heating costs. Then, the customized levels of the energy-saving attribute were equal to 25, 50 and 75 percent of the stated heating costs. If interviewees did not know or did not state their fuel bill, annual costs of 14 euros per square metre have been assumed. ${ }^{4}$ This corresponds with an annual heating energy consumption of 200 kilowatt hours per square metre, at a price of 0.07 euros per kilowatt hour. ${ }^{5}$

Long payback periods are a crucial barrier for carrying out modernisation measures, following evidence from recent surveys in Germany (BMVBS, 2007; Stieß et al., 2010). According to BMVBS (2007), only three percent of owners and tenants are willing to accept payback periods of 12 or more years. Likewise, Stieß et al. (2010) identify a period of 15 years as acceptance limit for most house owners. As pointed out by Jakob (2007), the payback period of energy-saving measures is highly uncertain and depends on various factors. In particular, the assumed interest rate and time horizon determine the capital costs related to such measures, while energy prices and their development determine the marginal costs of heat generation. We explicitly included the payback period in our choice experiment to take these issues into account, but removed the related uncertainty.

By including both energy-saving potential and $\mathrm{CO}_{2}$ savings, interviewees had to evaluate trade-offs among cost savings and environmental benefits. Though somewhat hypothetical, we are therefore able to quantify the effect, if any, of environmental benefits on choices of energy-saving measures. Previous studies on energy-saving measures, however, had a slightly different focus and are lacking this feature. As Banfi et al. (2008) state, their WTP estimates "includes comfort benefits and cost savings as well as the respondents' potential valuation of environmental benefits".

In order to capture the impact of a professional's recommendation on choices,

\footnotetext{
${ }^{4} 15.6$ percent of the final regression sample did not state their heating costs.

${ }^{5}$ Both values are reasonable assumptions for Germany, given the average heating energy consumption of single-family detached, semidetached and row houses (BMVBS, 2007) and the average prices for natural gas and domestic heating oil in 2008 (BMWi, 2010).
} 
we included the opinion of an independent energy adviser as attribute. In Germany, various professionals have the right to provide on-site energy advice, in general, and energy passes, in particular, for existing buildings (EnEV, 2009). Architects, engineers and physicists, among others, with focus on energy-saving building during their study or relevant professional experience, as well as skilled craftsmen with further training on energy-saving building can be called energy adviser, though there is no such official job description. Independent energy advice, for example, is available from the consumer advice centre and publicly sponsored by the Federal Ministry of Economics and Technology.

In Germany, there exist several public funding programmes to encourage investments in energy-saving measures. For example, the KfW bank (Reconstruction Loan Corporation) offers grants and credits at reduced rates of interest for refurbishment measures designed to reduce home energy consumption. Private companies conceivably give discounts on their products and services, too. In the experiment we used funding just as a qualitative attribute, and let the acquisition costs already include possible grants or subsidies. We therefore avoid obtaining two different price elasticities, but are still able to study the effect of funding on choices per se.

Guarantee in this context means that for the given period of time the builder or contractor is obligated to remedy deficiencies free of charge. In case no period of limitation has been contractually agreed, it is regulated by the German Construction Contract Procedures (GCCP/VOB) that, for example, contractors are liable for defects of heating and insulation systems for at least two years. If within that period of limitation any defect actually has to be remedied, then another two-year period starts for this product or service. Some builders and contractors are providing longer periods of guarantee, mostly coupled with maintenance contracts. In case of insolvency or bankruptcy, all contractor's rights and obligations, including guarantees, are undertaken by insolvency insurance, if the contractor is member of the Chamber of Crafts (which is mandatory in Germany).

Given two alternatives, each described by seven attributes, each of which has two to five levels, the total number of possible combinations was far too big to let interviewees face all of them. Therefore, an orthogonal fractional factorial design was employed, using Sawtooth software. In the end, each interviewee was presented with 12 choice sets and asked to state which of the displayed alternatives seems 
Table 1: Used attributes and related levels (separated into energy-saving measures).

\begin{tabular}{|c|c|c|}
\hline Attributes & Heating system & Insulation \\
\hline $\begin{array}{l}\text { Acquisition costs (including, if any, public } \\
\text { and/or private funding) }\end{array}$ & $\begin{array}{l}€ 10,000 \\
€ 20,000 \\
€ 30,000\end{array}$ & $\begin{array}{l}€ 10,000 \\
€ 20,000 \\
€ 30,000 \\
€ 40,000\end{array}$ \\
\hline $\begin{array}{l}\text { Annual energy-saving potential at current } \\
\text { energy prices (including fuel and electricity } \\
\text { costs related to heating) }\end{array}$ & $\begin{array}{l}25 \% \\
50 \% \\
75 \% \\
\text { of current value, in } €\end{array}$ & $\begin{array}{l}25 \% \\
50 \% \\
75 \% \\
\text { of current value, in } €\end{array}$ \\
\hline $\begin{array}{l}\text { Payback period (number of years after which } \\
\text { the modernisation measure will pay off) }\end{array}$ & $\begin{array}{l}10 \text { years } \\
20 \text { years } \\
30 \text { years }\end{array}$ & $\begin{array}{l}10 \text { years } \\
20 \text { years } \\
30 \text { years }\end{array}$ \\
\hline $\mathrm{CO}_{2}$ savings & $\begin{array}{l}0 \% \\
25 \% \\
50 \% \\
75 \% \\
100 \%\end{array}$ & $\begin{array}{l}25 \% \\
50 \% \\
75 \%\end{array}$ \\
\hline Opinion of an independent energy adviser & $\begin{array}{l}\text { recommendable } \\
\text { blank }\end{array}$ & $\begin{array}{l}\text { recommendable } \\
\text { blank }\end{array}$ \\
\hline Public and/or private funding & $\begin{array}{l}\text { Yes } \\
\text { No }\end{array}$ & $\begin{array}{l}\text { Yes } \\
\text { No }\end{array}$ \\
\hline Period of guarantee & $\begin{array}{l}2 \text { years } \\
5 \text { years } \\
10 \text { years }\end{array}$ & $\begin{array}{l}2 \text { years } \\
5 \text { years } \\
10 \text { years }\end{array}$ \\
\hline
\end{tabular}

more attractive to him/her and choose it. ${ }^{6}$ Hensher et al. (2001) and Carlsson and Martinsson (2008) provide empirical evidence that, for example, a number of 12 choice sets is reasonable and does not significantly affect the results. Likewise, the used $7 \times 2$ choice set design is not too demanding for interviewees; larger matrices have been employed in previous studies (e.g., Brownstone et al., 1996; Goett et al., 2000).

\footnotetext{
${ }^{6}$ After each choice interviewees had made, we asked them whether they would actually carry out such a modernisation measure in their home if it already existed on the market. If we considered these answers too, we would virtually include a status-quo or no-choice alternative. Since our focus is on house owners' preferences for attributes and possible differences between heating and insulation alternatives, rather than forecasts or market shares, we go without it in this analysis.
} 


\section{$3.2 \quad$ Survey and sample}

The data used in this paper is a subsample of a larger survey among German households, carried out in June 2009. In order to guarantee the quality and the representativity of the sample we charged the market research company GfK Group with carrying out the survey. It was conducted in two stages. After recruiting individuals who match to the requested subsamples with telephone interviews, the first stage, individuals were visited at their homes for face-to-face interviews using the computer (CAPI method), in the second stage. The interviews took about 50 to 60 minutes on average. The questionnaire consisted basically of five parts and contained questions about attitudes towards the environment (part 1), the household's energy use (part 2), housing conditions (part 3), and socio-economic and demographic information (part 5). The choice experiment itself defined part 4 and is the main difference between the three gathered subsamples, each of which included more than 400 interviews. $^{7}$

As we were interested in individuals who really can make decisions on their heating supply and heating usage independently, only owner-occupiers of singlefamily detached houses, semidetached houses and row houses ${ }^{8}$, who do not use district heating, answered our choice experiment. Since in some German municipalities the use of district heating is mandatory, we excluded possibly affected house owners from the beginning. Moreover, the individuals had been explicitly asked, during the telephone screening, whether they are involved in household's energy-related decisions, like the choice of electricity supplier or heating technology. Only those who affirmed their involvement were finally recruited and interviewed. During the interview at stage two, individuals were further asked to state who predominantly makes energy-related decisions in their households. Approximately 51 percent stated "myself", 36 percent "me and my partner together", and 13 percent "my partner". Though studying choices that are relevant to the household as a whole, the choice experiment were answered by individuals. Obtained WTP estimates are therefore individuals' WTP which can differ from households' WTP, as discussed in Munro (2009).

\footnotetext{
${ }^{7}$ Besides the choice experiment described in subsection 3.1, analysed in this paper, two further choice experiments were conducted within this survey; one concerning TV sets and another concerning green electricity.

${ }^{8}$ In the following we will refer to them briefly as house owners.
} 
The final regression sample includes 379 house owners with 4548 observed choices. Table 2 gives details on the demographic profile and the types of houses of the sample.

\subsection{Model specification and estimation}

Data from choice experiments can be analysed econometrically with discrete choice models. Logit is the most common representative of this class of models; it has been applied in numerous empirical works on energy-saving measures (e.g., Sadler, 2003; Banfi et al., 2008; Kwak et al., 2010), and constitutes the basic model in this analysis, too. However, in order to address some of the limitations that standard logit models exhibit, we also use a mixed logit specification in this paper (e.g., Revelt and Train, 1998; Brownstone and Train, 1999; Goett et al., 2000, are providing relevant applications of mixed logit models).

Standard logit and the more general and flexible mixed logit model can both be derived from utility-maximising behaviour (Train, 2003). Meeting the requirements of repeated choices in the survey, the utility $U_{n j t}$ that person $n \in\{1, \ldots, N\}$ obtains from alternative $j \in\{1, \ldots, J\}$ in choice situation $t \in\{1, \ldots, T\}$ is modelled as a random variable

$$
U_{n j t}=\beta_{n}^{\prime} x_{n j t}+\varepsilon_{n j t}
$$

with attributes of the alternative and demographics of the person $x_{n j t}$, a related vector of coefficients $\beta_{n}$, and iid extreme value random term $\varepsilon_{n j t}$. Unlike standard logit, $\beta_{n}$ is allowed to vary over individuals with a specified density $f$ in a mixed logit specification. This specification represents random taste variation in the population. Since repeated choices by a person $n$ were all made within one interview, we assume $\beta_{n}$ to be constant over time. We thereby allow for correlation over time in the unobserved portion of utility of the mixed logit model.

However, the flexibility of mixed logit comes at a price. Unlike standard logit, the probability that person $n$ chooses a sequence of alternatives $\mathbf{i}=\left(i_{1}, \ldots, i_{T}\right)$, given by

$$
P_{n \mathbf{i}}=\int \prod_{t=1}^{T} \frac{\exp \left(\beta^{\prime} x_{n i_{t} t}\right)}{\sum_{j=1}^{J} \exp \left(\beta^{\prime} x_{n j t}\right)} f(\beta) \mathrm{d} \beta
$$


Table 2: Summary of the sample's demographics and houses.

\begin{tabular}{|c|c|}
\hline Survey question & Percent \\
\hline \multicolumn{2}{|l|}{ Demographics } \\
\hline \multicolumn{2}{|l|}{ Gender } \\
\hline Male & 61.0 \\
\hline Female & 39.0 \\
\hline \multicolumn{2}{|l|}{ Age } \\
\hline $24-35$ & 5.3 \\
\hline $36-45$ & 22.4 \\
\hline $46-55$ & 27.7 \\
\hline $56-65$ & 23.0 \\
\hline $66+$ & 21.6 \\
\hline \multicolumn{2}{|l|}{ Education } \\
\hline Without school degree & 0.3 \\
\hline Secondary modern school degree & 33.0 \\
\hline High school degree & 40.6 \\
\hline Academic high school degree & 11.6 \\
\hline University or college degree & 14.5 \\
\hline \multicolumn{2}{|l|}{ Household's monthly net income } \\
\hline Less than $€ 1,000$ & 4.5 \\
\hline$€ 1,000-1,499$ & 10.0 \\
\hline$€ 1,500-1,999$ & 15.0 \\
\hline$€ 2,000-2,499$ & 20.3 \\
\hline$€ 2,500-3,499$ & 18.5 \\
\hline$€ 3,500+$ & 14.8 \\
\hline Not stated & 16.9 \\
\hline Children $\leq 18$ in household & 28.5 \\
\hline \multicolumn{2}{|l|}{ Region } \\
\hline Western Germany & 81.8 \\
\hline Eastern Germany & 18.2 \\
\hline \multicolumn{2}{|l|}{ Number of inhabitants } \\
\hline $1-4,999$ & 31.4 \\
\hline $5,000-19,999$ & 28.5 \\
\hline $20,000-99,999$ & 25.9 \\
\hline $100,000-499,999$ & 8.4 \\
\hline $500,000+$ & 5.8 \\
\hline \multicolumn{2}{|l|}{ Houses } \\
\hline \multicolumn{2}{|l|}{ House type } \\
\hline Single-family detached house & 74.7 \\
\hline Semidetached house & 13.7 \\
\hline Row house & 11.6 \\
\hline \multicolumn{2}{|l|}{ Year of completion } \\
\hline Before 1948 & 22.4 \\
\hline 1949-1978 & 32.7 \\
\hline 1979-1986 & 12.9 \\
\hline $1987-1990$ & 6.9 \\
\hline 1991-2000 & 14.8 \\
\hline 2001-2009 & 10.3 \\
\hline
\end{tabular}


cannot be solved analytically ${ }^{9}$. It rather has to be approximated using simulation methods (Train, 2003). We use Halton draws with 500 replications for the maximum simulated likelihood estimation with Stata's mixlogit command (see Hole, 2007).

The independent variables that enter our models are briefly discussed in the following. Further details may be found in Table 3. Basically, we include the seven attributes that specified the alternatives in the choice experiment. In addition, a constant for the heating system alternative is included to capture the average effect of all unobserved factors; the insulation alternative thus serves as reference. After controlling for alternative-specific effects (i.e., whether the impact of the attributes varies across alternatives), we let two $\mathrm{CO}_{2}$-savings variables enter the models - one for each alternative. ${ }^{10}$ We further tested various demographic, socioeconomic, and other case-specific variables with a standard logit model. Those with a seemingly robust and significant influence on choices are included finally. These variables are: a house owner's age, educational level, region (Eastern vs. Western Germany), expectations for future fuel prices, and perceptions regarding the current state of home insulation, as well as the age and the fuel type of the currently installed heating system. While regional aspects have effect on the price sensitivity, the remaining variables seem to influence the preferences on energy-saving technologies, and enter the model as interactions with the alternative-specific constant (ASC). In so doing, we try to account for preference heterogeneity that can be explained by observed factors.

In the mixed logit model the ASC is specified with random coefficient. We therefore allow house owners' tastes regarding the energy-saving technologies to vary in the population - beyond observed factors. As there is no logically predefined sign for the ASC, we assume a normal distribution for the related coefficient. By including additional fixed-effects interaction terms between the ASC and the case-specific variables listed above, we allow the mean of the population distribution to vary deterministically (Andersen et al., 2009). The two $\mathrm{CO}_{2}$-savings

\footnotetext{
${ }^{9}$ In standard logit $f$ is a degenerate distribution. The choice probability $P_{n \mathbf{i}}$ then simplifies to the product of logit formulas under the integral sign in equation (2).

${ }^{10}$ There was also some indication for an alternative-specific effect for the energy-saving potential attribute. Energy-saving potential seems to matter slightly more for heating systems. However, the variation was rather small, and since the corresponding mixed logit specification failed to converge we include just the generic energy-saving variable.
} 
variables enter the mixed logit with log-normally distributed coefficients. In this wise we meet the assumption that nobody's utility increases with higher $\mathrm{CO}_{2}$ emissions. ${ }^{11}$

Although it may be expected that price sensitivity varies among individuals (beyond just regional aspects), both costs variables are specified with fixed coefficients. We follow Revelt and Train (1998) and Revelt and Train (2000) with this specification, since it simplifies the derivation of the distribution of the willingness to pay. Likewise, all remaining variables enter the mixed logit with fixed coefficients. We tested different random parameter specifications, but the simulated log-likelihood was not improved notably. Some of the tested specifications even failed to converge. As our focus lies on model fit rather than forecast, we go without additional random parameters and keep the model simple.

\section{Empirical results and discussion}

The estimation results are presented in Table 4. At first, we discuss the standard logit model; its estimated parameters and standard errors are given in column 2. It should be noted that we apply all 12 observed choices per interviewee for model estimation. In order to control whether, for example, fatigue by interviewees could have significantly affected choices and therefore model coefficients, we further estimated the model separately for the first and the last six choices only. Using a likelihood-ratio test, we compared the restricted model (i.e. all 12 choices) with the separately estimated models. The null hypothesis of equal coefficients across the first and the last six choices cannot be rejected at any common significance level $\left(\chi^{2}(16)=17.52\right)$. Hence, applying all 12 choices is reasonable.

As expected, energy-saving potential, recommendation of an independent energy adviser, funding, and period of guarantee enter the model positively signed, while the estimated coefficients of acquisition costs and payback period are negatively signed. All those coefficients differ significantly from zero at the $1 \%$ significance level. We further find a significant difference in price sensitivity between Eastern and Western Germany. It seems that Eastern German house owners' choices are more affected by the costs attribute, indicated by the negatively signed

\footnotetext{
${ }^{11}$ Unlike normal distribution, the log-normal one induces a positive coefficient sign for the whole population.
} 
Table 3: Variable definitions.

\begin{tabular}{|c|c|}
\hline Variable name & Definition \\
\hline Acquisition costs & Acquisition costs in thousands of euros \\
\hline Acquisition costs $\times$ East & $\begin{array}{l}\text { Acquisition costs in thousands of euros if } \\
\text { house owner lives in Eastern Germany (with- } \\
\text { out Berlin); zero otherwise }\end{array}$ \\
\hline Energy-saving potential & $\begin{array}{l}\text { Energy-saving potential in euros per year (at } \\
\text { current energy prices) }\end{array}$ \\
\hline Payback period & $\begin{array}{l}\text { Payback period in years (considering hypo- } \\
\text { thetical future energy prices) }\end{array}$ \\
\hline $\mathrm{CO}_{2}$ savings $\times$ Heating & $\begin{array}{l}\mathrm{CO}_{2} \text { savings in percent if alternative is heating } \\
\text { system; zero otherwise }\end{array}$ \\
\hline $\mathrm{CO}_{2}$ savings $\times$ Insulation & $\begin{array}{l}\mathrm{CO}_{2} \text { savings in percent if alternative is insula- } \\
\text { tion; zero otherwise }\end{array}$ \\
\hline Energy adviser & 1 for "recommendable"; zero otherwise \\
\hline Funding & 1 for "yes"; 0 for "no" \\
\hline Guarantee period & Period of guarantee in years \\
\hline Heating system & 1 for heating systems; zero otherwise \\
\hline Age $<46 \times$ Heating & $\begin{array}{l}1 \text { if interviewee is } 45 \text { years of age or younger } \\
\text { (and alternative is heating system); zero oth- } \\
\text { erwise }\end{array}$ \\
\hline Education $\times$ Heating & $\begin{array}{l}1 \text { if interviewee possess a higher education en- } \\
\text { trance qualification (and alternative is heating } \\
\text { system); zero otherwise }\end{array}$ \\
\hline New heating $\times$ Heating & $\begin{array}{l}1 \text { if interviewee's current heating system has } \\
\text { been installed after the year } 2000 \text { (and alter- } \\
\text { native is heating system); zero otherwise }\end{array}$ \\
\hline Wood-burning $\times$ Heating & $\begin{array}{l}1 \text { if interviewee's current heating system is } \\
\text { wood-burning (and alternative is heating sys- } \\
\text { tem); zero otherwise }\end{array}$ \\
\hline Price expectations $\times$ Heating & $\begin{array}{l}1 \text { if interviewee expects the price for his used } \\
\text { heating fuel to increase strongly (and alterna- } \\
\text { tive is heating system); zero otherwise }\end{array}$ \\
\hline State of insulation $\times$ Heating & $\begin{array}{l}1 \text { if interviewee states that there is no need } \\
\text { to improve the state of insulation at any part } \\
\text { of the building (and alternative is heating sys- } \\
\text { tem); zero otherwise }\end{array}$ \\
\hline
\end{tabular}


coefficient. We expect that existing differences in the levels of income between both German regions are mainly causing this phenomenon. These differences may actually be found in our sample. While 17 percent of surveyed Western Germans stated a household monthly net income of 3,500 euros or more, only 4 percent of Eastern Germans did so. ${ }^{12}$ Likewise, the percentage of low-income households (i.e., monthly net income below 1,000 euros) is bigger in the Eastern-German subsample (10 percent) than in the Western-German (4 percent). However, in preliminary analysis we used the income itself as explanatory variable and found no effects on price sensitivity. Since 17 percent of the sample did not make any statement about the household's monthly net income, we excluded it from further analysis.

As already mentioned in subsection 3.3, we find the impact of $\mathrm{CO}_{2}$ savings to vary across alternatives. Though positively signed for both alternatives, $\mathrm{CO}_{2}$ savings only enter the utility of heating systems significantly. A Wald test rejects the hypothesis of equal coefficients $\left(\chi^{2}=6.44\right)$. This finding is remarkable. Although both heating and insulation systems equally affect the energy efficiency and, hence, the $\mathrm{CO}_{2}$ emissions of residential buildings, environmental benefits of related energy-saving measures are not considered equally by house owners. Perhaps house owners associate the negative environmental impacts of burning fuel for heating more directly and strongly with the heating system itself. However, a rational explanation for this behavior is missing so far.

Not surprisingly, we find that the current state of the building envelope and the used heating system have an effect on house owners' choices. If the used heating system was installed after the year 2000, or is wood-burning, choosing the heating alternative is less likely. This suggests that house owners who use a rather new heating, and/or a rather cheap fuel, are satisfied with their current heating equipment and thus see no need for action. Likewise, choosing the heating alternative is more likely if house owners expect the price for their used heating fuel to increase strongly, or if there is no need to improve the state of insulation at any part of the building, in their view.

In addition, we find age and education to influence house owners' preferences on energy-saving measures. Interviewees 45 years of age or younger, who could

\footnotetext{
${ }^{12}$ Within the survey interviewees were asked to state the household's monthly net income. Predefined ranges were: below 1,000; between 1,000 and 1,499; between 1,500 and 1,999; between 2,000 and 2,499; between 2,500 and 3,499; and 3,500 euros or more.
} 
arguably be assumed to be less afraid of new technologies and state-of-the-art equipment, are more likely to choose the heating alternative. On the other hand, interviewees who possess a higher education entrance qualification (HEEQ) are more likely to choose the insulation alternative. The ASC itself enters the standard logit model significantly, and negatively signed. That is, factors that are not included in the model tend to increase the choice probability for the insulation alternative on average. Additional benefits of insulation, like maintaining a cool home during summer and increasing noise protection, possibly lead to this result.

Now we turn to the mixed logit model, with normally and log-normally distributed coefficients for the ASC and the $\mathrm{CO}_{2}$-savings variables, respectively. Columns 3-5 of Table 4 show the estimated parameters and standard errors. ${ }^{13}$ The mixed logit specification improves the fit significantly compared to the standard logit model (likelihood-ratio test: $\chi^{2}(3)=536.66$ ). Moreover, the significant standard deviation of the ASC coefficient indicates unobserved taste variation regarding heating systems in the population. However, the impact of case-specific variables which are included to capture observed preference heterogeneity regarding heating systems decreases. Though all coefficients have the same sign as in the standard logit, only education, price expectations and state of insulation enter the mixed logit significantly. ${ }^{14}$

The fixed coefficients of acquisition costs, energy-saving potential, payback period, energy adviser, funding, and guarantee period all keep their sign and significance level. Their increase in magnitude compared to the standard logit is expected and due to the different scale of utility (Brownstone and Train, 1999). Like in the standard logit, the impact of $\mathrm{CO}_{2}$ savings varies across alternatives. Again, the estimates suggest that house owners consider $\mathrm{CO}_{2}$ savings only in terms of heating systems as relevant attribute. Moreover, the mixed logit provides evidence for taste variation in the population, as the standard deviation of the heating related $\mathrm{CO}_{2}$ coefficient enters significantly.

\footnotetext{
${ }^{13}$ Note that Stata actually reports the estimated mean and standard deviation of the natural logarithm of log-normally distributed coefficients. The median, mean and standard deviation of the coefficient itself, as well as the related standard errors that are presented in Table 4 has been computed using Stata's nlcom command (see Hole, 2007).

${ }^{14}$ Note that the estimated parameters for the fixed-effects interaction terms between the ASC and the case-specific variables imply shifts in the mean of the population distribution of the ASC coefficient (Andersen et al., 2009).
} 
Table 4: The estimated standard and mixed logit models.

\begin{tabular}{|c|c|c|c|c|}
\hline \multirow[b]{2}{*}{ Variable } & \multirow{2}{*}{$\frac{\text { Standard logit }}{\text { Mean }}$} & \multicolumn{3}{|c|}{ Mixed logit } \\
\hline & & Mean & Median & $\mathrm{SD}$ \\
\hline Acquisition costs & $\begin{array}{l}-0.0401^{* * * *} \\
(0.00241)\end{array}$ & $\begin{array}{l}-0.0568^{* * *} \\
(0.00310)\end{array}$ & & \\
\hline Acquisition costs $\times$ East & $\begin{array}{l}-0.0257^{* * *} \\
(0.00552)\end{array}$ & $\begin{array}{l}-0.0187^{* * *} \\
(0.00707)\end{array}$ & & \\
\hline Energy-saving potential & $\begin{array}{l}0.000494^{* * *} \\
(6.08 \mathrm{e}-05)\end{array}$ & $\begin{array}{l}0.000625^{* * *} \\
(7.23 \mathrm{e}-05)\end{array}$ & & \\
\hline Payback period & $\begin{array}{l}-0.0186^{* * *} \\
(0.00233)\end{array}$ & $\begin{array}{l}-0.0235^{* * *} \\
(0.00278)\end{array}$ & & \\
\hline $\mathrm{CO}_{2}$ savings $\times$ Heating & $\begin{array}{l}0.00668^{* * *} \\
(0.000743)\end{array}$ & $\begin{array}{l}0.0114^{* * * *} \\
(0.00168)\end{array}$ & $\begin{array}{l}0.00500 * * * \\
(0.00120)\end{array}$ & $\begin{array}{l}0.0232^{* *} \\
(0.00929)\end{array}$ \\
\hline $\mathrm{CO}_{2}$ savings $\times$ Insulation & $\begin{array}{l}0.00213 \\
(0.00161)\end{array}$ & $\begin{array}{l}0.0432 \\
(0.0287)\end{array}$ & $\begin{array}{l}0.000543 \\
(0.000612)\end{array}$ & $\begin{array}{l}3.432 \\
(7.813)\end{array}$ \\
\hline Energy adviser & $\begin{array}{l}0.201^{* * *} \\
(0.0330)\end{array}$ & $\begin{array}{l}0.268^{* * *} \\
(0.0394)\end{array}$ & & \\
\hline Funding & $\begin{array}{l}0.153^{* * *} \\
(0.0330)\end{array}$ & $\begin{array}{l}0.198 * * * \\
(0.0389)\end{array}$ & & \\
\hline Guarantee period & $\begin{array}{l}0.0217^{* * *} \\
(0.00578)\end{array}$ & $\begin{array}{l}0.0256 * * * \\
(0.00686)\end{array}$ & & \\
\hline Heating system & $\begin{array}{l}-0.380^{* * *} \\
(0.109)\end{array}$ & $\begin{array}{l}-0.278^{*} \\
(0.143)\end{array}$ & & $\begin{array}{l}0.841^{* * *} \\
(0.100)\end{array}$ \\
\hline New heating $\times$ Heating & $\begin{array}{l}-0.288^{* * *} \\
(0.0730)\end{array}$ & $\begin{array}{l}-0.148 \\
(0.155)\end{array}$ & & \\
\hline Age $<46 \times$ Heating & $\begin{array}{l}0.276^{* * *} \\
(0.0750)\end{array}$ & $\begin{array}{l}0.203 \\
(0.150)\end{array}$ & & \\
\hline Education $\times$ Heating & $\begin{array}{l}-0.251^{* * *} \\
(0.0759)\end{array}$ & $\begin{array}{l}-0.306^{*} \\
(0.158)\end{array}$ & & \\
\hline Wood-burning $\times$ Heating & $\begin{array}{l}-0.269^{* * *} \\
(0.104)\end{array}$ & $\begin{array}{l}-0.186 \\
(0.221)\end{array}$ & & \\
\hline Price expectations $\times$ Heating & $\begin{array}{l}0.197^{* * *} * \\
(0.0683)\end{array}$ & $\begin{array}{l}0.289^{* *} \\
(0.142)\end{array}$ & & \\
\hline State of insulation $\times$ Heating & $\begin{array}{l}0.580^{* * * *} \\
(0.0805)\end{array}$ & $\begin{array}{l}0.431^{* * *} \\
(0.164)\end{array}$ & & \\
\hline Observed choices & 4548 & 4548 & & \\
\hline Persons & 379 & 379 & & \\
\hline Log likelihood & -2688.92 & -2420.59 & & \\
\hline Pseudo R2 & 0.147 & 0.232 & & \\
\hline
\end{tabular}

\footnotetext{
Standard errors in parentheses

*** $\mathrm{p}<0.01,{ }^{* *} \mathrm{p}<0.05,{ }^{*} \mathrm{p}<0.1$
} 
However, the insights that can be directly drawn from parameters in a nonlinear model are very limited. A useful way to quantify and interpret the impact of $\mathrm{CO}_{2}$ savings, or any other attribute, is to look at the ratios of estimated parameters. If the denominator is the coefficient of a monetary variable, the ratio represents the marginal willingness to pay (WTP).

Based on the mixed logit model, we derive the average WTP for an increase of one percentage point in $\mathrm{CO}_{2}$ savings for the heating system alternative. As $\mathrm{CO}_{2}$ savings do not significantly enter the utility function of the insulation alternative, no meaningful WTP could be obtained from that. Rows 1-4 of Table 5 present the WTP based on the acquisition costs, separated into Eastern ${ }^{15}$ and Western German house owners, while the bottom two rows gives the WTP based on the energysaving potential. As both monetary variables have fixed coefficients, the respective WTP follows the same distribution as the $\mathrm{CO}_{2}$-savings coefficient (i.e. log-normal distribution; see Figures 1-3 for illustration). In the following discussion we will refer to the median WTP, which divides the cumulative distribution function in half. ${ }^{16}$

Western German house owners' average median WTP is 88 euros. This means that for each percentage point a heating system saves on $\mathrm{CO}_{2}$ emissions additionally, its acquisition costs could rise by approximately 88 euros, without any change in utility and thus choice probability (given that all other attributes are unchanged). The median WTP of Eastern German house owners is smaller due to the larger costs coefficient. On average, they are willing to pay 66.2 euros for the same increase in $\mathrm{CO}_{2}$ savings. Based on the energy-saving potential, the average median WTP can be translated into 8 euros per year. However, it is important to note that the given WTP measures are point estimates which are measured with uncertainty. We also have to take into account the standard errors. For instance, the $95 \%$ confidence interval on the median WTP based on energy-savings ranges from 3.9 to 12.1 euros per year.

\footnotetext{
${ }^{15}$ Note that the sum of both costs coefficients gives the actual acquisition costs coefficient for Eastern German house owners.

${ }^{16}$ Note that in a (right-skewed) log-normal distribution the standard deviation has a significant positive effect on the mean. Since in our models the estimated standard deviations for the WTP measures are relatively high (indicating very heterogeneous preferences and resulting in a high skewness of distributions), the much less outlier-sensitive median seems to be the appropriate measure of central tendency here.
} 
The obtained WTP measures are substantial. Of course, it is not straightforward to translate them into a WTP per tonne of $\mathrm{CO}_{2}$. Given the fact that we could not observe each household's heating energy consumption, we do not know what their total emissions actually are. The $\mathrm{CO}_{2}$ emissions that arise from heating a residential building depend on various factors. Among others, the heating system and fuel, the state of insulation of the building envelope, the ratio of surface of a building to its volume, and the heated living area per member of household are crucial. Therefore, an approximation of each household's emissions is difficult and would require a specific analysis of each individual case. However, this goes beyond the scope of this paper and cannot be performed on the basis of the present data. Nonetheless, we may provide a rough calculation by assuming that an average house emits approximately 6.5 tons of $\mathrm{CO}_{2}$ per year. ${ }^{17}$ Based on this figure, the average median WTP based on energy-savings could be translated into a WTP of 123.1 euros per tonne $\mathrm{CO}_{2}$ (with $95 \%$ confidence interval between 59.3 to 186.6 euros).

Our results are lying in between those of former studies. Nonetheless, WTP estimates obtained from stated preference methods have to be treated with some caution. Since stated choices by interviewees lack the monetary commitment, overestimating the true WTP is possible. This phenomenon is referred to as hypothetical bias. Murphy et al. (2005) conducted a meta-analysis to assess the magnitude of the hypothetical bias and reported the median ratio of hypothetical to actual value to be only 1.35 , with choice-based methods being important in reducing hypothetical bias. In a choice experiment, however, the scaling of the price/cost vector may possibly have an impact on the estimated WTP. For instance, Carlsson and Martinsson (2008) found the marginal WTP to be consistently higher in an otherwise completely identical version of a choice experiment, with levels of the cost attribute being doubled. On the other hand, Hanley et al. (2005) also investigated the effects of changing price vectors in choice experiments and found no significant impact on estimates of WTP. By including two monetary attributes in our experiment, we are somewhat able to control whether those effects might be a serious issue in this study. The average WTP for saving one extra euro per year

\footnotetext{
${ }^{17}$ In Germany exist approximately 17.3 million residential buildings which directly accounted for 113 million tons of $\mathrm{CO}_{2}$ in 2005 (BMVBS, 2007). It should be noted that those figures do also include blocks of flats, but not indirect emissions arising from the generation of electricity or district heating.
} 
Table 5: The estimated willingness to pay measures (in euros).

\begin{tabular}{llll}
\hline & Mean & Median & SD \\
\hline $\begin{array}{l}\text { WTP of Western Germans } \\
\text { (based on acquisition costs) }\end{array}$ & $200.3^{* * *}$ & $88.0^{* * *}$ & $409.2^{* *}$ \\
WTP of Eastern Germans & $(30.8)$ & $(21.6)$ & $(164.4)$ \\
(based on acquisition costs) & $150.6^{* * *}$ & $66.2^{* * *}$ & $307.8^{* *}$ \\
WTP & $(25.6)$ & $(16.8)$ & $(125.9)$ \\
(based on energy-savings per year) & $18.2^{* * *}$ & $8.0^{* * *}$ & $37.1^{* *}$ \\
\hline $\begin{array}{l}\text { Standard errors in parentheses } \\
* * *\end{array}<0.01, * *$ p $<0.05, *$ p $<0.1$ & $(3.4)$ & $(2.1)$ & $(15.5)$ \\
\hline
\end{tabular}

is 11.02 euros (8.29 euros for Eastern German house owners), which seems to be reasonable values, given the long-term character of the considered energy-saving measures. This result rather suggests that hypothetical bias and the used scale of the cost vector do not affect the presented estimates.

\section{Summary and conclusion}

Residential buildings strongly contribute to global $\mathrm{CO}_{2}$ emissions due to the high energy demand for electricity and heating, particularly in industrialised countries. Within the EU, decentralised heat generation is of particular relevance for future climate policy, as its emissions are not covered by the EU ETS. We conducted a choice experiment concerning energy retrofits for existing houses in Germany. In the experiment, the approximately 400 sampled house owners could either choose a modern heating system or an improved thermal insulation for their home. We used standard and mixed logit specifications to analyse the choice data. We found environmental benefits to have a significant impact on choices of heating systems. However, they played no role in terms of insulation choices. Based on the estimated mixed logit model, we further obtained WTP measures for $\mathrm{CO}_{2}$ savings.

The (residential) building sector is already highly regulated in Germany, as discussed above. Nonetheless, it remains an open question whether the regulations in force are appropriate. The crucial criterion those regulations should meet is cost efficiency (i.e. to achieve an aim at the lowest possible cost). Standards as prescribed by ESO and REHA are unlikely to meet cost efficiency, since standards usually ignore differences in individual marginal abatement costs. Considering people's preferences generally helps to design policy instruments that make good 
economic sense. In particular, it allows to value benefits of environmental and climate policy. Given the relatively high WTP for $\mathrm{CO}_{2}$ savings concerning heating systems we can conclude that people are aware of their responsibility and willing to contribute to climate protection. Therefore, private households seem to be an appropriate and promising unit to address future climate and energy policy.

However, there are a lot of uncertainties and intransparencies which hinder investments in energy-efficient technologies in the real world, but which were abstracted in the experiment. In reality, people do not know for sure how energy prices will develop in the long run, what the concrete energy and $\mathrm{CO}_{2}$ savings of new technologies will be, when investments will pay off, or how long they will live in their current home. Further, getting informed about existing energy-saving measures may be associated with high costs of searching. As a consequence, underinvestments are likely to occur. Future policies should address the market failure of information asymmetry and reduce related uncertainties as far as possible, rather than implement further and stricter standards. The recently introduced energy pass, for example, is supposed to tackle information asymmetry on the residential property market. Credits at reduced rates of interest for investments in energy efficiency, as already provided by KfW, properly designed, may help to overcome information asymmetry on capital markets. Moreover, in order to increase the trustworthiness of the more and more confusing market of energy advising in Germany, an official certification system should be introduced.

Given the existing empirical evidence on WTP for climate policy and its varying results, it remains the task for future research to figure out what the determining influences are. Besides (expectable) varying preferences across different countries, the respective circumstances seem to play a crucial role. Apparently, it makes a difference whether people are asked for their willingness to pay higher prices for gasoline, airline tickets, or energy-efficient heating systems. As a consequence, there is no unique carbon price. Moreover, the specific elicitation method might be influential too. However, results of this study particularly suggest that $\mathrm{CO}_{2}$ savings were affecting heating choices but not insulation choices - though using the very same elicitation method. Whether this is due to a lack of information, psychological reasons, or just complex preferences on behalf of the surveyed people needs to be clarified in future. 
Figure 1: WTP of Western Germans based on acquisition costs.

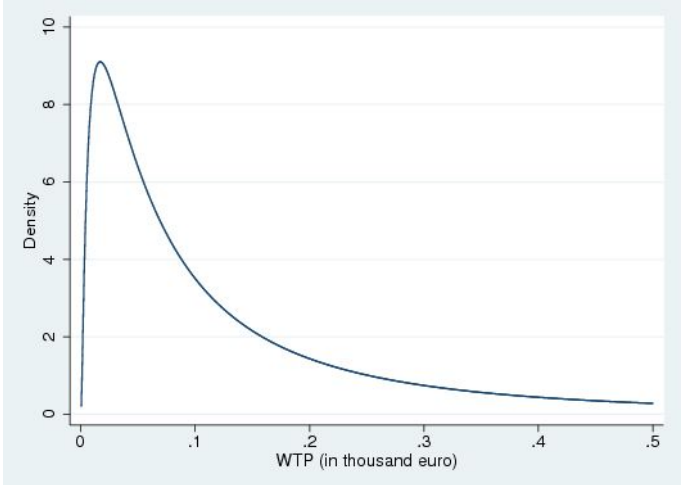

Figure 2: WTP of Eastern Germans based on acquisition costs.

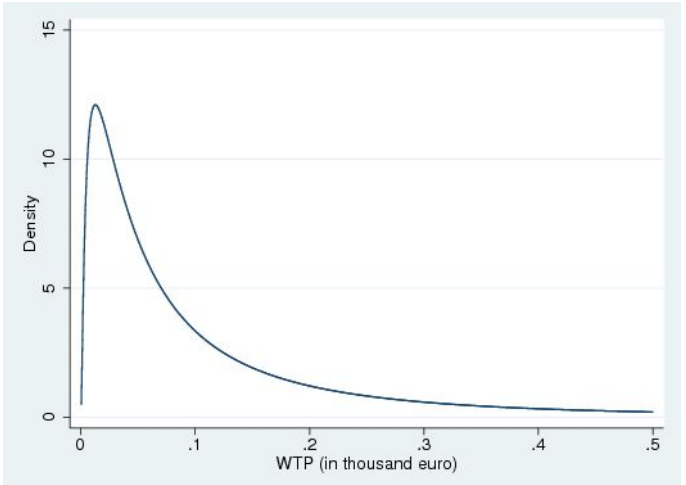

Figure 3: WTP based on energy-savings per year.

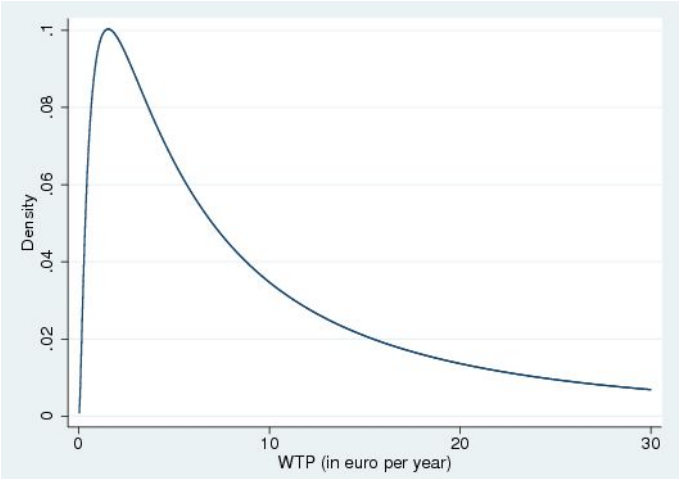




\section{Acknowledgements}

This paper was mainly written during a research stay at the University of California, Irvine. I would like to thank David Brownstone for his invitation and valuable comments on this work, and the German Academic Exchange Service (DAAD) for financial support. Further, I am thankful for suggestions from Fredrik Carlsson, Martin Kesternich, Bodo Sturm and Thure Traber. Funding from the German Federal Ministry of Education and Research is also gratefully acknowledged (Förderkennzeichen: 01UV0810A).

\section{References}

Achtnicht, M., 2009. German car buyers' willingness to pay to reduce CO2 emissions. ZEW Discussion Paper No. 09-058, Mannheim.

Andersen, S., Harrison, G.W., Hole, A.R., Rutström, E.E., 2009. Non-linear mixed logit and the characterization of individual heterogeneity. Working paper series 6-2009, CBS Copenhagen Business School, Department of Economics, Frederiksberg.

Banfi, S., Farsi, M., Filippini, M., Jakob, M., 2008. Willingness to pay for energysaving measures in residential buildings. Energy Economics 30, 503-516.

Berrens, R.P., Bohara, A.K., Jenkins-Smith, H.C., Silva, C.L., Weimer, D.L., 2004. Information and effort in contingent valuation surveys: Application to global climate change using national internet samples. Journal of Environmental Economics and Management 47, 331-363.

BMVBS (Federal Ministry of Transport, Building and Urban Development), 2007. $\mathrm{CO}_{2}$ Gebäudereport 2007. Federal Ministry of Transport, Building and Urban Development, Berlin.

BMWi (Federal Ministry of Economics and Technology), 2010. Energiestatistiken Entwicklung von Energiepreisen und Preisindizes. Federal Ministry of Economics and Technology, Berlin.

URL: http://www.bmwi.de/BMWi/Navigation/Energie/energiestatistiken,did =180914.html (accessed on: 11 May 2010). 
Brouwer, R., Brander, L., Van Beukering, P., 2008. "A convenient truth": Air travel passengers' willingness to pay to offset their $\mathrm{CO}_{2}$ emissions. Climatic Change 90, 299-313.

Brownstone, D., Bunch, D., Golob, T., Ren, W., 1996. Transactions choice model for forecasting demand for alternative-fuel vehicles. Research in Transportation Economics 4, 87-129.

Brownstone, D., Train, K.E., 1999. Forecasting new product penetration with flexible substitution patterns. Journal of Econometrics 89, 109-129.

Carlsson, F., Martinsson, P., 2008. How much is too much? An investigation of the effect of the number of choice sets, context dependence and the choice of bid vectors in choice experiments. Environmental and Resource Economics 40, 165-176.

EEWärmeG (Renewable Energies Heat Act), 2009. Gesetz zur Förderung Erneuerbarer Energien im Wärmebereich (Erneuerbare-Energien-Wärmegesetz - EEWärmeG). Bundesgesetzblatt Jahrgang 2008 Teil I Nr. 36 S. 1658, Bonn.

EnEV (Energy Savings Ordinance), 2007. Verordnung über energiesparenden Wärmeschutz und energiesparende Anlagentechnik bei Gebäuden (Energieeinsparverordnung - EnEV). Bundesgesetzblatt Jahrgang 2007 Teil I Nr. 34 S. 1519, Bonn.

EnEV (Energy Savings Ordinance), 2009. Verordnung zur Änderung der Energieeinsparverordnung. Bundesgesetzblatt Jahrgang 2009 Teil I Nr. 23 S. 954, Bonn.

EU (European Union), 2002. Directive 2002/91/EC of the European Parliament and of the Council of 16 December 2002 on the energy performance of buildings. Official Journal of the European Communities L1/65, Brussels.

EU (European Union), 2010. Directive 2010/31/EU of the European Parliament and of the Council of 19 May 2010 on the energy performance of buildings (recast). Official Journal of the European Union L153/13, Strasbourg. 
Goett, D., Hudson, K., Train, K., 2000. Customer choice among retail energy suppliers: The willingness-to-pay for service attributes. The Energy Journal 21(4), 1-28.

Grösche, P., Vance, C., 2009. Willingness-to-pay for energy conservation and freeridership on subsidization - Evidence from Germany. The Energy Journal 30(2), 135-154.

Hanley, N., Adamowicz, W., Wright, R.E., 2005. Price vector effects in choice experiments: An empirical test. Resource and Energy Economics 27, 227-234.

Hensher, D.A., Stopher, P.R., Louviere, J.J., 2001. An exploratory analysis of the effect of numbers of choice sets in designed choice experiments: An airline choice application. Journal of Air Transport Management 7(6), 373-379.

Hersch, J., Viscusi, W.K., 2006. The generational divide in support for environmental policies: European evidence. Climatic Change 77, 121-136.

Hole, A.R., 2007. Fitting mixed logit models by using maximum simulated likelihood. The Stata Journal 7, 388-401.

IEA (International Energy Agency), 2009. World Energy Outlook 2009. OECD/IEA, Paris.

IWU (Institut Wohnen und Umwelt), 2007. Basisdaten für Hochrechnungen mit der Deutschen Gebäudetypologie des IWU. Darmstadt.

URL: http://www.iwu.de/fileadmin/user_upload/dateien/energie/klima_altbau /Flaechen_Gebaeudetypologie_07.pdf (accessed on: 13 May 2010).

Jakob, M., 2007. The drivers of and barriers to energy efficiency in renovation decisions of single-family home-owners. Working paper series 07-56, CEPE Center for Energy Policy and Economics, ETH Zurich.

Johnson, E., Nemet, G.F., 2010. Willingness to pay for climate policy: A review of estimates. La Follette School Working Paper No. 2010-011, University of Wisconsin-Madison.

Kwak, S.-Y., Yoo, S.-H., Kwak, S.-J., 2010. Valuing energy-saving measures in residential buildings: A choice experiment study. Energy Policy 38, 673-677. 
Lindén, A.-L., Carlsson-Kanyama, A., Eriksson, B., 2006. Efficient and inefficient aspects of residential energy behaviour: What are the policy instruments for change? Energy Policy 34, 1918-1927.

Louviere, J.J., Hensher, D.A., Swait, J.D., 2000. Stated choice methods - Analysis and applications. Cambridge University Press, Cambridge.

MacKerron, G.J., Egerton, C., Gaskell, C., Parpia, A., Mourato, S., 2009. Willingness to pay for carbon offset certification and co-benefits among (high-)flying young adults in the UK. Energy Policy 37, 1372-1381.

Munro, A., 2009. Introduction to the special issue: Things we do and don't understand about the household and the environment. Environmental and Resource Economics 41, 1-10.

Murphy, J.J., Allen, P.G., Stevens, T.H., Weatherhead, D., 2005. A meta-analysis of hypothetical bias in stated preference valuation. Environmental and Resource Economics 30, 313-325.

Poortinga, W., Steg, L., Vlek, C., Wiersma, G., 2003. Household preferences for energy-saving measures: A conjoint analysis. Journal of Economic Psychology 24, 49-64.

Revelt, D., Train, K.E., 1998. Mixed logit with repeated choices: Households' choices of appliance efficiency level. Review of Economics and Statistics Vol. LXXX, No. 4, 647-657.

Revelt, D., Train, K.E., 2000. Customer-specific taste parameters and mixed logit. Working Paper, University of California, Berkley.

Sadler, M., 2003. Home energy preferences and policy: Applying stated choice modeling to a hybrid energy economic model. Report to Natural Resources Canada, Simon Fraser University.

Solomon, B.D., Johnson, N.H., 2009. Valuing climate protection through willingness to pay for biomass ethanol. Ecological Economics 68, 2137-2144. 
Stieß, I., van der Land, V., Birzle-Harder, B., Deffner, J., 2010. Handlungsmotive, -hemnisse und Zielgruppen für eine energetische Gebäudesanierung. Project report, commissioned by the Federal Ministry of Education and Research. Frankfurt am Main.

URL: http://www.enef-haus.de/fileadmin/ENEFH/redaktion/PDF/Befragung EnefHaus.pdf (accessed on: 6 May 2010).

Train, K.E., 2003. Discrete choice methods with simulation. Cambridge University Press, Cambridge.

Viscusi, W.K., Zeckhauser, R.J., 2006. The perception and valuation of the risks of climate change: A rational and behavioral blend. Climatic Change 77, 151-177. 